\title{
Peningkatan Keterampilan Berpikir Kreatif Siswa Kelas 5 Menggunakan Model Mind Mapping
}

\author{
*Fitriana Ayu Wulandari'1, Mawardi ${ }^{2}$, Krisma Widi Wardani ${ }^{3}$
}

1,2,3 Pendidikan Guru Sekolah Dasar Universitas Kristen Satya Wacana Indonesia

\author{
A R T I C L E I N F O \\ Article history: \\ Received 10 November \\ 2018 \\ Received in revised form \\ 09 December 2018 \\ Accepted 15 January 2019 \\ Available online 25 \\ February 2019
}

Kata Kunci:

skills, creative thinking,

mind mapping.

\begin{abstract}
A B S T R A K
Rendahnya keterampilan berfikir kreatif siswa dengan model pemebelajaran konvensional. Penelitian yang dilakukan untuk mengetahui peningkatan keterampilan berpikir kreatif siswa. Khususnya pada siswa kelas 5 sekolah dasar. Tujuan penelitian ini adalah untuk meningkatkan keterampilan berpikir kreatif siswa. Model yang digunakan yaitu model Mind Mapping. Mind Mapping adalah model pembelajaran yang berfungsi untuk menuangkan ide-ide atau gagasan yang menimbulkan percikan-percikan kreatifitas yang diperoleh otak yang bertujuan untuk meningkatkan keterampilan berpikir kreatif siswa. Hasil penelitian menunjukan adanya peningkatan keterampilan berpikir kreatif siswa menggunakan model mind mapping. Hal ini dibuktikan dengan rata-rata persentase yang diperoleh siswa dari tahap pra siklus dengan persentase $28,6 \%$ pada kategori sangat kreatif, pada siklus I
\end{abstract} meningkat menjadi 33,3\% pada kategori sangat kreatif dan pada siklus II meningkat menjadi $61,9 \%$. Dengan demikian penerapan model Mind Mapping sangat membantu siswa dalam meningkatkan keterampilan berpikir kreatif dalam penuangan ide-ide baru.

\section{A B S T R A C T}

This research conducted to determine the improvement of students' creative thinking skills. Especially for 5th grade students in elementary school. The purpose of this study is to improve students' creative thinking skills. The model used is the Mind Mapping model. Mind Mapping is a learning model that functions to express ideas or ideas that give rise to the spark of creativity acquired by the brain which aims to improve students' creative thinking skills. The results of the study showed an increase in students' creative thinking skills using mind mapping models. This is evidenced by the average percentage obtained by students from the pre-cycle stage with a percentage of $28.6 \%$ in the very creative category, in the first cycle it increased to $33.3 \%$ in the very creative category and in the second cycle it increased to $61.9 \%$. Thus the application of the Mind Mapping model is very helpful for students in improving their creative thinking skills in pouring new ideas.

\section{Pendahuluan}

Kurikulum 2013 adalah sebuah kurikulum yang berlaku dalam sistem pendidikan di Negara Indonesia. Kurikulum ini merupakan kurikulum tetap diterapkan oleh pemerintah Indonesia untuk menggantikan Kurikulum 2006 (yang sering disebut sebagai Kurikulum Tingkat Satuan Pendidikan) yang telah berlaku selama kurang lebih 6 tahun. Pembelajaran tahun 2014/2015 mulai menggunakan Kurikulum 2013, khususnya pada jenjang pendidikan dasar. Pada pelaksanaan pembelajaran kurikulum 2013 yang sekarang diselenggarakan di beberapa sekolah, menekankan pada proses pembelajaran yang berbasis pada pengembangan aktivitas kognitif siswa yang kreatif produktif.

Puskurbuk (Retnawati, 2016) berpendapat bahwa Kurikulum 2013 diharuskan dapat menghasilkan sumber daya manusia yang produktif, kreatif inovatif dan afektif, melalui penguatan kompetensi sikap, pengetahuan, dan keterampilan. Khususnya pada aspek keterampilan terdapat empat keterampilan berpikir siswa yaitu critical thinking (berfikir kritis), communication (komunikasi), collaboration (kolaborasi), dan Creative Thinking (berpikir kreatif) (Yuniar, S.T., Sunardi, 2017). Salah

Copyright (C) Universitas Pendidikan Ganesha. All rights reserved. 
satu keterampilan yang harus ditingkatkan dalam pembelajaran kurikulum 2013 adalah keterampilan berpikir kreatif (Creative Thinking).

Berpikir kreatif merupakan tahap berpikir dengan menyesuaikan suatu jawaban yang baik dan benar untuk membantu siswa memiliki kemampuan melihat suatu masalah dari berbagai sudut pandang dan mampu melahirkan banyak gagasan, (Selwanus, 2010). Proses berpikir melibatkan beberapa tahap dan dalam pola yang saling berganti atau saling melengkapi. (Anwar, Shamim-ur-Rasool, \& Haq, 2012) mengemukakan berfikir kreatif adalah cara baru dalam melihat dan mengerjakan sesuatu yang memuat 4 aspek antara lain, fluency (kefasihan), flexybility (keluwesan), originality (keaslian), dan elaboration (keterincian). Berdasarkan hasil pengamatan yang dilakukan di Sekolah Dasar Negeri Cebongan 01 Salatiga, saat ini guru masih cenderung memakai metode ceramah dan belum menggunakan metode dan model yang menarik untuk siswa sehingga siswa masih cenderung pasif dan tingkat kekreatifan mereka rendah. Diperoleh data dari hasil observasi dan wawancara guru kelas 5 SD Negeri Cebongan 01 yang berjumalah 21 siswa, terdapat $6(28,6 \%)$ siswa masuk kedalam kategori sangat kreatif, 7 (33,3\%) dalam kategori kreatif, dan 8 (38,1\%) siswa masuk dalam kategori cukup kreatif. Siswa sulit menuangkan ide-ide yang mereka punya karena mereka hanya mendengarkan penjelasan dari guru. Siswa belum dapat mencari alternatif lain untuk menyelesaikan soal.

Berpikir pada umumnya didefinisikan sebagai proses mentalyang dapat menghasilkan pengetahuan. Berpikir adalah suatukegiatan akal untuk mengolah pengetahuan yang telah diperolehmelalui indra dan ditujukan untuk mencapai kebenaran (Rakhmat,1991: 138). (Maxwell, 2004: 82) mengartikan berpikir sebagai segalaaktivitas mental yang membantu merumuskan atau memecahkanmasalah, membuat keputusan, atau memenuhi keinginan untukmemahami; berpikir adalah sebuah pencarian jawaban, sebuahpencapaian makna.Menurut Khodijah (2006: 81) berpikir adalah melatih ide-idedengan cara yang tepat dan seksama yang dimulai dengan adanyamasalah. (Solso, dalam Khodijah, 2006: 94) berpikir adalah sebuahproses dimana representasi mental baru dibentuk melalui transformasiinformasi dengan interaksi yang komplek atribut-atribut mental sepertipenilaian, abstraksi, logika, imajinasi, dan pemecahan masalah.

Permasalahan pembelajaran seperti diatas diperlukan tindakan agar masalah yang terjadi di dalam kelas dapat segera dipecahkan. Berdasarkan permasalahan yang ada di dalam kelas diharapkan guru mampu melakukan pembelajaran yang sesuai dengan kurikulum 2013 dengan memanfaatkan model yang sesuai untuk meningkatkan keterampilan berpikir kreatif siswa yang rendah. Peneliti menemukan solusi dalam meningkatkan keterampilan berpikir kreatif siswa kelas 5 SD Negeri Cebongan 01 dengan penggunaan model pembelajaran yang sesuai yaitu mind mapping. Tujuan penelitian ini dilakukan untuk meningkatkan keterampilan berpikir kreatif siswa kelas 5 SD Negeri Cebongan 01 dengan menggunakan model mind mapping. Pembelajaran dilakukan dengan menekankan tahapan yang terdapat dalam mind mapping yaitu menyampaikan kompetensi yang dilakukan oleh guru, identifikasi masalah oleh siswa, pengelompokan siswa, pemecahan masalah, penyampaian hasil diskusi, dan pembuatan kesimpulan.

Mind mapping merupakan salah satu model pembelajaran yang tepat untuk meningkatkan keterampilan berpikir kreatif siswa. (Porter, 2008) mind mapping juga dapat disebut dengan peta pemikiran. Mind mapping juga merupakan metode mencatat secara menyeluruh dalam satu halaman. Mind mapping menggunakan pengingat-pengingat visual dan sensorik dalam suatu pola dari ide-ide yang berkaitan. Berdasarkan pengertian diatas dapat disimpulkan mind mapping adalah model pembelajaran yang berfungsi untuk menuangkan ide-ide atau gagasan yang menimbulkan percikan-percikan kreatifitas yang diperoleh otak yang bertujuan untuk meningkatkan keterampilan berpikir kreatif siswa. Model ini merupakan model yang sering digunakan guru dalam proses pembelajaran dalam upaya menumbuhkan kreativitas dan prestasi siswa. seorang.

Mind Map atau Mind Mapping, seperti yang diungkapkan Buzan (2011) adalah cara mencatat yang kreatif, efektif dan secara harfiah akan "memetakan" pikiran-pikiran. Kelebihan Mind Map, Mind Map akan memberikan pandangan menyeluruh tentang pokok masalah atau area yang luas, memungkinkan kita merencanakan rute atau membuat pilihan-pilihan, mengumpulkan sejumlah besar data di suatu tempat, mendorong pemecahan masalah dengan membiarkan kita melihat jalan-jalan terobosan kreatif, dan menyenangkan untuk dilihat, dibaca, dicerna dan diingat. Model pembelajaran Mind Map adalah salah satu model pembelajaran yang meminta peserta didik untuk membuat gambar/ diagram tentang konsep utama yang saling berhubungan, ditandai oleh garis yang melengkung yang menghubungkan ke cabangcabang yang kedua dan ketiga. Model pembelajaran Mind Map juga adalah salah satu model pembelajaran aktif(Putri, 2016).

Sejalan dengan penelitian yang pernah dilakukan oleh beberapa peneliti sebelumnya penggunaan model mind mapping dapat meningkatkan keterampilan, kemampuan dan hasil belajar siswa. Seperti halnya penelitian yang sudah dilakukan oleh (Sulistiyaningsih, 2010), penggunaan model mind mapping dapat meningkatkan kemampuan menulis siswa kelas V SD, (Darusman, 2014)), penerapan model mind 
mapping (peta pikiran) dapat meningkatkan kemampuan berpikir kreatif matematik siswa, (I Wayan Darmayoga, 2013), implementasi mind mapping dapat memberikan pengaruh dan peningkatan terhadap hasil belajar siswa kelas IV., (Wana, Pangestu, \& Agustina, 2017), penggunaan model pembelajarn mind mapping dapat meningkatkan hasil belajar siswa, (Kurniawati, 2010).

Melakukan penelitian tentang pengaruh metode mind mapping dan keaktifan belajar siswa terhadap prestasi belajar ilmu pengetahuan sosial. (Hayati, 2013) melakukan penelitian tindakan kelas tentang perbandingan strategi pembelajaran mind map dan concept map terhadap prestasi belajar siswa. (Wicaksana, 2012) melakukan penelitian tentang penerapan pembelajaran ipa dengan strategi mind mapping (peta pikiran) terhadap hasil belajar siswa. (Sucianingtyas, Sugiharto, \& Utomo, 2013). Melakukan penelitian tentang peta konsep (mind mapping) dalam pembelajaran struktur aljabar. (Rahayu, 2016). Melakukan penelitian tentang Peningkatan Karakter Tanggung Jawab Siswa SD Melalui Penilaian Produk Pada Pembelajaran Mind Mapping. (Muthoharoh, 2017) Melakukan sebuah penelitian tentang studi komparasi metode pembelajaran student teams achievement division (stad) menggunakan peta pikiran (mind mapping) dan peta konsep (concept mapping) terhadap prestasi belajar siswa. (Saifudin, 2012) melakukan penelitian tentang Upaya Peningkatan Hasil Belajar dan Kreativitas siswa melalui pembelajaran Peta Konsep pada Mata Pelajaran IPS kelas V.

Dapat disimpulkan bahwa penggunaan model pembelajaran mind mapping dapat digunakan dalam upaya peningkatan keterampilan, kemampuan dan hasil belajar siswa. Model ini sangat menarik karena semua siswa ikut serta dalam pembuatan mind mapping. Siswa akan membuat dengan ide-ide yang menarik yang dituangkan dalam pengerjaaan pembelajaran dengan model mind mapping sehingga memicu munculnya keterampilan kreatif peserta didik. Dengan penggunaan model mind mapping keterampilan kreatif peserta didik menjadi lebih meningkat di bandingkan dengan penggunaan metode ceramah yang saat ini para guru masih sering menggunakannya.

\section{Metode}

Penelitian yang digunakan yaitu Penelitian Tindakan Kelas (PTK). Penelitian Tindakan Kelas (PTK) merupakan salah satu model penelitian yang relevan dilakukan guru untuk memecahkan masalah pembelajaran di kelas dan memperbaiki kualitas pembelajaran. Metode penelitian yang dilakukan menggunakan desain Kemmis dan McTaggart yang berupa siklus yang meliputi : perencanaan (planning), tindakan (action), pengamatan (observing), refleksi (reflecting). Tindakan dilakukan 2 kali, siklus I dan siklus II. Dalam penelitian upaya peningkatan keterampilan berpikir kreatif yang dilakukan dengan menggunakan model pembelajaran mind mapping. Penelitian ini dilakukan di Sekolah Dasar Negeri Cebongan 01 Salatiga yang berlokasi di Jalan Cebongan Raya RT.02 RW.01 Kecamatan Argomulyo Kota Salatiga. Dengan subjek penelitian siswa kelas V SD Negeri Cebongan 01 yang berjumlah 21 siswa terdiri dari 12 putra dan 9 putri.

Teknik pengumpulan data dilakukan melalui wawancara, dokumentasi, dan observasi. Instrumen penelitian terdiri atas rubrik penilaian dan pengembangan keterampilan berpikir kreatif yang dilakukan dengan membuat mind mapping. Terdapat 4 aspek dalam keterampilan berpikir kreatif yaitu aspek fluency (kefasihan), flexybility (keluwesan), originality (keaslian), dan elaboration (keterincian), selanjutnya dijabarkan melalui rubrik penilaian, rubrik penilaian ini berjumlah 8 item instrumen rubrik penilaian yang digunakan dalam pengukuran keterampilan berpikir kreatif. Peneliti mempersiapkan lembar observasi aktivitas guru dan siswa yang digunakan untuk meneliti jalannya pembelajaran yang dilakukan.

Analisis data yang digunakan peneliti yaitu SPSS 20 untuk menguji validitas dan reabilitas intrumen keterampilan berpikir kreatif. Penerapan model mind mapping dalam pembelajaran ini yaitu dengan memberikan tugas siswa untuk menyelesaikan masalah dengan cara membuat mind mapping secara berkelompok. Tahapan yang terdapat dalam model mind mapping yaitu 1). Tahap penyampaian kompetensi yang dilakukan oleh guru. Guru memberikan penjelasan materi yang akan dipelajari. 2). Identifikasi masalah dilakukan oleh siswa, siswa mulai megindentifikasi pemasalahan yang diberikan 3). Pengelompokan siswa, bersama kelompok siswa mulai berdiskusi tentang pemasalahan. 4). Pemecahan masalah, siswa bersama kelompok mulai berdiskusi tentang pemecahan masalahan dalam tugas pembuatan mind mapping. 5). Penyampaian hasil diskusi, perwakilan dari kelompok menyampaikan hasil diskusi ke depan kelas 6). Membuat kesimpulan, siswa bersama dengan guru membuat kesimpulan tentang apa yang di presentasikan di depan kelas. 


\title{
3. Hasil dan Pembahasan
}

Berdasarkan data yang diperoleh dapat dilihat peningkatan keterampilan berpikir kreatif siswa yang diperoleh siswa dengan jumlah 21 siswa. Tingkat ketrampilan berpikir kreatif siswa kelas V SD Negeri Cebongan 01 pada kondisi pra siklus, siklus I dan siklus II sebagai berikut

Tabel 1. Rekapitulasi keterampilan berpikir kreatif pra siklus, siklus I dan siklus II

\begin{tabular}{ccccccccc}
\hline No & Interval & Kt. & \multicolumn{2}{c}{ prasiklus } & \multicolumn{2}{c}{ Siklus I } & \multicolumn{2}{c}{ Siklus 2 } \\
\cline { 3 - 8 } & & & $\mathrm{F}$ & $\%$ & $\mathrm{~F}$ & $\%$ & $\mathrm{~F}$ & $\%$ \\
\hline $\mathbf{1}$ & $27-32$ & $\mathrm{SK}$ & 6 & $28,6 \%$ & 7 & $33,3 \%$ & 13 & $61,9 \%$ \\
$\mathbf{2}$ & $21-26$ & $\mathrm{~K}$ & 7 & $33,3 \%$ & 10 & $47,6 \%$ & 6 & $28,6 \%$ \\
$\mathbf{3}$ & $15-20$ & $\mathrm{CK}$ & 8 & $38,1 \%$ & 4 & $19,1 \%$ & 2 & $9,5 \%$ \\
& Jumlah & & 21 & $100 \%$ & 21 & $100 \%$ & 21 & $100 \%$ \\
\hline
\end{tabular}

\author{
Keterangan : \\ Kt : Kategori \\ Sk : Sangat Kreatif \\ $\mathrm{K}:$ Kreatif \\ CK : Cukup Kreatif
}

Dari Tabel 1 diperoleh data dalam kondisi prasiklus bahwa dari 21 siswa kelas V SD Negeri Cebongan 01 terdapat $6(28,6 \%)$ siswa memperoleh skor pada interval 27-32 atau berada pada kategori sangat kreatif, 7 (33,3\%) siswa memperoleh skor pada interval 21-26 atau berada pada kategori kreatif dan $8(38,1 \%)$ memperoleh skor pada interval 15-20 atau berada pada kategori cukup. Pada kondisi siklus I diperoleh data bahwa dari 21 siswa kelas V SD Negeri Cebongan 01 terdapat 7 (33,3\%) siswa memperoleh skor pada interval 27-32 atau berada pada kategori sangat kreatif, 10 (47,6\%) siswa memperoleh skor pada interval 21-26 atau berada pada kategori kreatif dan $4(19,1 \%)$ memperoleh skor pada interval 15-20 atau berada pada kategori cukup sedangkan pada kondisi siklus II diperoleh data bahwa dari 21 siswa kelas V SD Negeri Cebongan 01 terdapat 13 (61,9\%) siswa memperoleh skor pada interval 27-32 atau berada pada kategori sangat kreatif, 6 (28,6\%) siswa memperoleh skor pada interval 21-26 atau berada pada kategori kreatif dan 2 (9,5\%) memperoleh skor pada interval 15-20 atau berada pada kategori cukup.

Berdasarkan hasil penelitian yang telah dilaksanakan pada kelas V di SD Negeri Cebongan 01 semester II tahun ajaran 2018/2019 diketahui adanya peningkatan keterampilan berpikir kreatif siswa pada kegiatan pembelajaran siklus I dan siklus II dan penerapan model mind mapping. Hal ini dapat diketahui adanya peningkatan keterampilan berpikir kreatif dari prasiklus sampai siklus 2. Hasil penelitian menunjukan bahwa terdapat peningkatan keterampilan berpikir kreatif yang diupayakan melalui model pembelajaran mind mapping antar siklus yakni prasiklus $28,6 \%$ pada kategori sangat kreatif, pada siklus I terjadi peningkatan menjadi 33,3\% pada kategori sangat kreatif, dan pada siklus 2 terjadi peningkatan menjadi $61,9 \%$ pada kategori sangat kreatif.

Berdasarkan hasil penelitian yang sudah di lakukan penggunaan model mind mapping terbukti dapat meningkatkan keterampilan berpikir kreatif. Dalam penelitian yang digunakan peneliti menggunakan model mind mapping, adapun langkah-langkah pembelajaran model mind mapping adalah sebagai berikut: 1). Penyampaian Kompetensi, guru memberikan penjelasan tentang materi yang dipelajari dan menyampaikan permasalahan yang harus dipercahkan siswa, siswa menyimak penjelasan guru. 2). Identifikasi masalah, dilakukan siswa dalam upaya menemukan permasalahan yang akan dipecahkan. 3). Mengelompokan siswa, guru mengelompokan siswa ke dalam kelompok belajar sesuai dengan tingkat pemahaman masing-masing untuk mendiskusikan tugas. 4). Pemecahan masalah, siswa mulai berdiskusi dengan kelompok tentang masalah yang perlu dipecahkan dalam pembuatan mind mapping. 5). Penyampaian hasil diskusi, perwakilan dari kelompok menyampaikan hasil diskusinya di depan kelas. 6). Membuat kesimpulan, siswa bersama-sama dengan guru membuat kesimpulan berdasarkan hasil presentasi.

Berfikir kreatif adalah cara baru dalam melihat dan mengerjakan sesuatu, yang memuat 4 aspek antara lain, 1). fluency (kefasihan), dilihat dari cara siswa membangun ide dalam membuat Mind Mapping, pembuatan Mind Mapping berdasarkan ide yang diperoleh dan mengembangkan ide baru dalam membuat Mind Mapping 2). flexybility (keluwesan), dilihat dari pemecahan masalah yang dilakukan siswa dalam pembuatan mind mapping. 3). Originality (keaslian), dapat dilihat dari hasil karya yang benar-benar dibuat oleh siswa dan bukan dari modifikasi hasil karya milik orang lain. 4). elaboration (keterincian), 
dapat dilihat dari cara siswa menyampaikan hasil diskusinya di depan kelas. Tindakan penelitian ini dilaksanakan dengan berkolaborasi dengan guru kelas 5, pada tindakan ini dilaksanakan dalam 2 siklus dan setiap siklusnya terdiri dari 2 pertemuan. Berdasarkan penelitian yang dilakukan dalam dua siklus dapat disimpulkan bahwa model pembelajaran mind mapping yang diterapkan pada kelas V SD Negeri Cebongan 01 semester II tahun ajaran 2018/2019 dapat meningkatkan keterampilan berpikir kreatif pada pembelajaran tematik.

Sejalan dengan penelitian yang telah peneliti lakukan terdapat hasil penelitian terdahulu yang memperkuat hasil penelitian bahwa keterampilan berpikir kreatif dapat ditingkatkan melalui penggunaan model mind mapping. Penelitian dilakukan oleh Eny Sulistiyaningsih (2010), dalam penelitiannya yang berjudul peningkatan kemampuan menulis narasi dengan metode peta pikiran (mind mapping) pada siswa kelas V SD Negeri Karangasem III Surakarta tahun pelajaran 2010/2011. Pada siklus II siswa mengalami peningkatan hingga 85\% mencapai ketuntasan. Rijal Darusman (2014). Melakukan penelitian tentang penerapan metode mind mapping (peta pikiran) untuk meningkatkan kemampuan berpikir kreatif matematika. Hasil penelitian menyebutkan bahwa Pencapaian kemampuan berpikir kreatif matematika siswa, yang pembelajarannya menggunakan mind mapping lebih baik daripada yang cara konvensional. Wayan Darmayoga, Wayan Lasmawan, dan Marhaeni (2013), dalam penelitiannya yang berjudul pengaruh implementasi metode mind mapping terhadap hasil belajar ips ditinjau dari minat siswa kelas IV SD Sathya Sai Denpasar. Hasil penelitian menujukan bahwa adanya peningkatan hasil belajar siswa dengan penerapan model mind mapping. Prima Rias wana, Widya Trio Pangestu dan Degi Alrinda Agustina (2017).

Melakukan penelitian tentang Perbandingan Prestasi Belajar Matematika Siswa Dengan Menggunakan Metode Pembelajaran Mind Mapping Dan Direct Instruction Pada Siswa Kelas V SDN Jiwan 01 Madiun. Dari hasil penelitian dapat diperoleh hasil prestasi belajar matematika yang dilakukan dengan metode mind mapping lebih baik dari pada siswa dengan metode Direct Instruction. (Kurniawati, 2010). Melakukan penelitian tentang pengaruh metode mind mapping dan keaktifan belajar siswa terhadap prestasi belajar ilmu pengetahuan sosial pada siswa. (Hayati, 2013). Melakukan penelitian tindakan kelas tentang perbandingan strategi pembelajaran mind map dan concept map terhadap prestasi belajar siswa. (Wicaksana, 2012) melakukan penelitian tentang penerapan pembelajaran ipa dengan strategi mind mapping (peta pikiran) terhadap hasil belajar siswa. Berdasarkan hasil penelitian terjadi peningkatan yang semula mencapai persentase $19,4 \%$ naik meningkat menjadi $38,7 \%$ yang masuk kategori sangat baik. Muhammad chomsi imaduddin dan unggul haryanto nur utomo. melakukan penelitian tentang efektifitas metode mind mapping untuk meningkatkan prestasi belajar. (Yunita \& Wijayanti, 2017).

Melakukan penelitian tentang peta konsep (mind mapping) dalam pembelajaran struktur aljabar. (Rahayu, 2016), melakukan penelitian tentang Peningkatan Karakter Tanggung Jawab Siswa SM Melalui Penilaian Produk Pada Pembelajaran Mind Mapping. Berdasarkan hasil penelitian dan pembahasan penelitian tindakan kelas, diperoleh simpulan bahwa pembelajaran mind mapping dengan penilaian produk pada pelajaran matematika materi persegi dan persegi panjang dapat meningkatkan karakter tanggung jawab siswa kelas III SD 1 Peganjaran Kudus tahun pelajaran 2015/2016. Peningkatan karakter tanggung jawab siswa dari 72,5\% pada siklus I menjadi $82,8 \%$ pada siklus II. 11). Nurul Fauziah, M.Masykuri, dan Agung Nugroho (2013), melakukan sebuah penelitian tentang studi komparasi metode pembelajaran student teams achievement division (stad) menggunakan peta pikiran (mind mapping) dan peta konsep (concept mapping) terhadap prestasi belajar siswa. Rina Werdi Astari (2010). Melakukan sebuah penelitian tentang Peningkatan Kemampuan Menulis Puisi Dengan Model Pembelajaran Mind Mapping. Ridwan Nur Cahyo Nugroho (2011).

Melakukan penelitian tentang Penggunaan Metode Pembelajaran Mind Map Untuk Meningkatkan Kreativitas Dan Hasil Belajar Ekonomi Siswa. Ramlan Silaban dan Masita Anggraini Napitupulu. Melakukan penelitian tentang Pengaruh Media Mind Mapping Terhadap Kreativitas Dan Hasil Belajar. (Saifudin, 2012)), melakukan penelitian tentang Upaya Peningkatan Hasil Belajar dan Kreativitas siswa melalui pembelajaran Peta Konsep pada Mata Pelajaran IPS kelas V SDN Tuntang 02. Hasil yang diperoleh dalam penelitian ini adalah terjadinya peningkatan hasil belajar dan kreativitas siswa kelas V SDN Tuntang 02 pada mata pelajaran IPS melalui metode peta konsep yang ditandai dengan meningkatnya ketuntasan hasil belajar siswa. Presentase siswa yang tuntas dalam belajar hanya $43,75 \%$ dan setelah adanya tindakan pada siklus I meningkat menjadi $71,88 \%$ dan pada siklus II mengalami peningkatan lagi $90,25 \%$. Begitu juga dengan kreativitas siswa.

\section{Simpulan dan Saran}

Terdapat peningkatan keterampilan berpikir kreatif siswa kelas $\mathrm{V}$ dengan penerapan model pembelajaran Mind Mapping. Pembelajaran menjadi aktif dan tidak monoton. Hal ini dapat memicu siswa 
untuk berantusias dan bersemangat dalam mengikuti pembelajaran. Siswa menjadi aktif dan dapat dengan mudah menuangkan ide-ide yang mereka punya. Siswa dapat menyelesaikan masalah dengan ide yang mereka kembangkan sendiri. Dibuktikan dengan adanya peningkatan keterampilan berpikir kreatif yang semula hanya $28,6 \%$ pada siklus I meningkat menjadi $33,3 \%$ dan $61,9 \%$ pada siklus II dengan kategori sangat kreatif.

Adapun saran dari penelitian ini adalah sebagai berikut: 1) Bagi Guru : dapat menggunakan model pembelajaran yang menarik agar siswa berantusias dan bersemangat dalam mengikuti pembelajaran. Gunakan model yang sesuai dan tiak monoton, 2) Bagi Siswa : tingkatkan rasa ingin tahu, kembangkan ide-ide yang dipunyai, dan gali rasa ingin tahu terus-menerus, 3) Bagi Peneliti lain : perlu dilakukan penelitian lanjutan yang lebih luas agar dunia pendidikan semakin terbuka dan memahami upaya peningkatan keterampilan berpikir siswa agar kualitas pendidikan lebih maju untuk kedepan.

\section{Daftar Rujukan}

Anwar, M. N., Shamim-ur-Rasool, S., \& Haq, R. (2012). A Comparison of Creative Thinking Abilities of High and Low Achievers Secondary School Students. International Interdisciplinary Journal of Education, $1(1), 3-8$.

Darusman, R. (2014). Penerapan Metode Mind Mapping (Peta Pikiran) Untuk Meningkatkan Kemampuan Berpikir Kreatif Matematik Siswa Smp. Infinity Journal, 3(2), 164. https://doi.org/10.22460/infinity.v3i2.61

Hayati, N. (2013). Perbandingan strategi pembelajaran mind map dan concept map terhadap prestasi belajar siswa kelas VII SMP Negeri 2 Sawit Boyolali tahun ajaran 2012/2013.

I Wayan Darmayoga, I. W. L. dan A. A. I. N. M. (2013). Hasil Belajar Ips Ditinjau Dari Minat Siswa Kelas Iv. I Wayan Darmayoga, I Wayan Lasmawan Dan A.A.I.N. Marhaeni, 3.

KURNIAWATI, D. D. (2010). Pengaruh metode mind mapping dan keaktifan belajar siswa terhadap prestasi belajar ilmu pengetahuan sosial pada siswa kelas viii sekolah menengah pertama muhammadiyah 5 surakarta tahun pelajaran 2009 / 2010.

Muthoharoh, N. B. (2017). Pengaruh Model Pembelajaran Kooperatif "Think Pair Share" terhadap Hasil Belajar Bahasa Inggris. SAP (Susunan Artikel Pendidikan), 2(1), 33-42. https://doi.org/10.30998/sap.v2i1.1509

Porter, D. B. dan H. (2008). Quantum Learning: Membiasakan Belajar Nyaman dan Menyenangkan. Bandung: Kaifa.

Putri, L. O. L. (2016). Mind map sebagai model pembelajaran menilai penguasaan konsep dan alat evaluasi menilai kemampuan berpikir kreatif siswa. Seminar Nasional Pendidikan Dan Saintek 2016, 2.

Rahayu, R. (2016). Peningkatan Karakter Tanggung Jawab Siswa Sd Melalui Penilaian Produk Pada Pembelajaran Mind Mapping. Jurnal Konseling Gusjigang, 2(1). https://doi.org/10.24176/jkg.v2i1.562

Retnawati, H. (2016). Hambatan Guru Matematika Sekolah Menengah Pertama Dalam Menerapkan Kurikulum Baru. Jurnal Cakrawala Pendidikan, 3(3), 390-403. https://doi.org/10.21831/ cp.v3i3.7694

Saifudin, M. H. (2012). Melalui pembelajaran peta konsep pada mata pelajaran IPS kelas V SDN tuntang 02 kecamatan tuntang kabupaten semarang progam studi s1 pendidikan guru sekolah DASAR Hasan , Maulana . 28200103 . 2012 . Upaya Peningkatkan Hasil Belajar Dan Kelas V Sdn Tuntang.

Selwanus, R. A. (2010). Pembelajaran IPS dengan Metode Problem Solving Untuk Meningkatkan Kemampuan Berfikir Kreatif Siswa di SD Negeri Naikoten Satu Kota Kupang. Tesis Pendidikan Dasar, Program Pascasarjana Universitas Negeri Surabaya.

Sucianingtyas, R., Sugiharto, S., \& Utomo, S. (2013). Studi Komparasi Penggunaan Media Teka-Teki Silang (Tts) Dengan Kartu Pada Pembelajaran Kimia Melalui Pendekatan Contextual Teaching and Learning (Ctl) Terhadap Prestasi Belajar Siswa Pada Materi Zat Adiktif Dan Psikotropika Kelas Viii Smp N 2 Ngadirojo. Jurnal Pendidikan Kimia Universitas Sebelas Maret, 2(3), 68-76.

Sulistiyaningsih, E. (2010). Peningkatan kemampuan menulis narasi dengan metode peta pikiran (mind mapping) pada siswa kelas V SD Negeri Karangasem III Surakarta tahun pelajaran 2010/2011. (Doctoral dissertation, UNS).

Wana, P. R., Pangestu, W. T., \& Agustina, D. A. (2017). Perbandingan Prestasi Belajar Matematika Siswa Dengan Menggunakan Metode Pembelajaran Mind Mapping Dan Direct Instruction Pada Siswa Kelas V Sdn Jiwan 01 Madiun. Trihayu: Jurnal Pendidikan Ke-SD-An, 3(2), 83-88.

Wicaksana, R. B. (2012). Penerapan Pembelajaran IPA dengan Strategi Mind Mapping (Peta Pikiran) Terhadap Hasil Belajar Siswa Pada Materi Ekosistem Kelas VII SMPN 3 Madiun. Pensa E-Jurnal, 9-25.

Yuniar, S.T., Sunardi, D. K. (2017). Pengembangan Indikator 4C's yang Selaras Dengan Kurikulum 2013 
SMA Kelas X Pada Materi Trigonometri. Kadikma, 8(3).

Yunita, D., \& Wijayanti, A. (2017). Pengaruh Media Video Pembelajaran Terhadap Hasil Belajar Ipa Ditinjau Dari Keaktifan Siswa. Sosiohumaniora: Jurnal Ilmiah Ilmu Sosial Dan Humaniora, 3(2), 153160. https://doi.org/10.30738/sosio.v3i2.1614 